\title{
CIVIC BUDGETS IN CITIES OF GREATER POLAND REGION IN 2018
}

\author{
Małgorzata HARTWICH ${ }^{1 *}$, Robert ROMANOWSKI ${ }^{2}$ \\ ${ }^{1}$ SKN Marketing, Poznań University of Economics and Business; mhartwich@op.pl, \\ ORCID: 0000-0002-2536-4308 \\ ${ }^{2}$ Poznań University of Economics and Business; robert.romanowski@ue.poznan.pl, \\ ORCID: 0000-0002-8585-6806 \\ * Corresponding author
}

Purpose: the purpose of the elaboration is a review of civic budget projects in cities of Wielkopolska (Greater Poland region) in 2018 with a view to compliance with the smart city concept.

Design/methodology/approach: (mandatory) The study was carried out in three stages. At the first stage, websites of all 113 cities in Wielkopolska were reviewed (full study in FebruaryApril 2020), which allowed to diagnose the level of implementation of civic budgets in the surveyed population in 2018 . At the second stage, information on all correctly submitted project applications (915) and the number of finally selected projects for implementation (279) were collected. In the third stage, ten winning projects were selected, based on using the information and communication technologies (ICT). Due to the difficulty of verifying activities in terms of being smart, a fairly simplified technological criterion was adopted, assuming that in order to achieve the smart city 2.0 phase a systemic approach based on the rapid flow of information between different devices is required.

Findings: Only 40\% of cities in Greater Poland region created civic budgets which leaves a lot of space for improvements. Projects selected for implementation under civic budgets are still largely of investment nature. A considerable number of tasks related to sport, culture and tourism were reported. At the first stage, smart city projects focus on simple activities improving life, especially in the area of smart living, while attempts to implement system solutions within smart city $2.0+$ phases are carried out at this stage only in the Poznań agglomeration.

Research limitations/implications: it is worth repeating the research on the quality of projects approved for implementation under civic budgets in every Polish region, with extended understanding of smart city projects beyond the use of ICT. Such a comprehensive list could be helpful for the formulation of urban policy assumptions, which is required at the smart city 2.0 and 3.0 phases.

Originality/value The paper fills a research gap regarding the limited resource of publications related to the description and classification of prevailing projects in a regional approach.

Keywords: smart city, civic budgets, co-creation, social innovations, local development.

Category of the paper: research paper. 


\section{Introduction}

Issue of creating the civic budgets was present in the last century both in practice and in the literature. First performance based on the participatory budget was proceeded in 1989 in Porto Allegre (Brasil). Other cities started copying the procedure although it had not been so popular until 2000. The real civic budgets boom took place in the XXI century when in first decade 1500 cities implemented this solution in the public management. The participatory budgets were different and still are in many places regarding the procedure, range or objectives (Gałecki, 2013).

In the Polish literature, descriptions of individual cities solutions dominate. BurchardDziubińska (2016) and Wiśniewska (2018) wrote about civic budget in Łódź, description of civic budget of Wrocław was shown by Tatarowska i Furmankiewicz (2018), Krawczyk (2016) wrote about improving the model of Częstochowa civic budget and Studencka (2017) presented the consequences of civic budgets projects in Katowice for spatial management. However, there is a research gap regarding the limited resource of publications related to the description and classification of prevailing projects especially in a regional approach.

Moreover significant premises of the presented topic are relatively new law regulations regarding civic budgets. Polish legislation did not include the term of civic budget until 2018. Article no. 5a of a municipal government act (1990) pointed only the possibility of carrying out a consultation with residents. Basing on this article, municipal councils started to implement civic budgets and define the procedures of conducting these budgets on their territory (Sobol, 2017).

The situation had changed on the 11th of January 2018 when the act of increasing the involvement of citizens in the public life came into force (2018). The meaning of the civic budget was brought thereunder. Admittedly in art. 1, sec. 1, point b)4) of the act from 2018 this definition was not formulated directly - it is said that "under the civic budget every year residents are deciding on the part of municipal budget expenses in a direct voting" but this formulation can be adopted as a definition of a civil budget. It means that the civic budget is a separated part of financial resources of the territorial entity budget (typically of the city) which allocation is determined by members of the local community. It is a tool of engaged participation although choices of citizens are subjective. The aim of the civic budget is to support the creation of a civil society thus to lead to the dialogue between the local authorities and the community (Wampler, 2007), (Laurisz, 2013), (Lukomska-Szarek, 2014), (Jeran, Mączka, Matczak i Milewicz, 2017), (Kołodziej-Hajdo, 2017).

The relevant change included the cities with county rights for which creating a civic budget happened to be the obligation. Minimum amount of the civil budget was set, which cannot be less than $0,5 \%$ of the commune expenses, put in the latest budget implementation report. 
Financial supervision is handled by regional financial chambers due to the correlation of the civic budget and the municipality budget.

Establishing the procedure of carrying out the civic budget on the commune territory or identifying requirements of submitted projects are still in competences of municipal councils. Projects outvoted by residents have to be included in the budget resolution of the commune and councilors cannot remove or make big adjustments (Daniel, 2019).

Taking a research gap and present regulations into consideration, the purpose of the elaboration is a review of civic budget projects in cities of Wielkopolska (Greater Poland region) in 2018 with a view to compliance with the smart city concept. For achieving the goal an overview for all of the submitted and implemented projects in cities of Wielkopolska had been made in 2018 (full research) using available public information.

\section{Phases of smart city}

The term smart city is presented very extensively in the literature and the consequence of that is the existence of a lot of definitions (more about that (Lewicki i Romanowski, 2017). Also in Poland examinations of smart city concept are undertaken. The biggest interest in this area is shown by researchers of geographical and economic sciences (Masik i Studzińska, 2018).

The lack of universal smart city definition creates a problem with referring to the particular author. Literature shows two main definition axis which tell what a smart city is. In the first approach, the core of high-tech and its inclusion in the greater city operating is emphasized. Integration of ICT technology with the city infrastructure leads to economic growth, social capital growth and sustainable resources exploitation (Komninos, 2008). What is more, usage of the modern ICT technologies develops interactivity and efficiency of the city infrastructure and depended elements (Obrębalski, 2016). Second smart city approach is orientated to a greater extent on a human and social capital, natural environment and education - including high-tech (Lombardi, Giordano, Farouh i Yousef, 2012). This approach seems to accord more legibly with sustainable development principles.

Smart city concept has evolved and its generations are reflected in implemented smart solutions in a city tissue. Originally initiators of smart actions were private companies and representatives of the ICT sector that cared about adaptation of modern technologies in the city - in the literature (Cohen, 2015) this model is called Smart City 1.0. (technology driven). Producers cared about implementation of their final products, however the solutions were not necessarily bringing the added value for the city (for instance urban card or CCTV) because they were not adjusted to the city characteristics. Integration of solutions was not considered and city authorities were not fully aware of the final effects. Nowadays, we can also talk about 
Smart City 1.0 - an extreme example of that smart city phase is a city built from the scratch like Masdar in the United Arab Emirates or Songdo in South Korea (Rudewicz, 2019).

The next phase, Smart City 2.0 (city led) assumes a holistic approach towards implemented solutions which leads to a selective integration of systems based on mutual benefits. The involvement of city stakeholders is much bigger, especially of city authorities which are participating in a decisive process regarding to modern solutions location. Authorities are identifying needs of urban centre more deliberately and they are defining the expectations towards producers by making projects and programmes, leading in an implementation process of new solutions, raising funds for them and relying on their own expertise (Zawieska, 2016), (Rudewicz, 2019).

Generation of Smart City 3.0. (co-creation city) rely on a fully integrated systems which often leads to city-wide investment strategies. It assumes an active contribution of decision makers and local authorities in creating new and innovative solutions which have a chance to respond not only to infrastructural needs but also to social and economic ones. Local authorities play the role of the observer or the assistant more often that supports the communication between inhabitants and tenderer of new technologies. Technology is treated as a tool used to improve life conditions of urban community. In this generation strong emphasis is on the social capital activation and collaborative economy (Zawieska, 2016) (Rudewicz, 2019).

In the literature the term Smart City 4.0 is timidly starting to appear. The phase is based on the presumption, that a smart city is simultaneously a sustainable city but still developing and modern solutions optimize urban infrastructure and create a space for a social integration (Paliński, 2019). Cohen (2015) claims that cities can go through mentioned phases from one to another for instance from 1.0 to 3.0 or undergo all of the phases at the same time. Usually there is a hybrid of Smart City 2.0 and 3.0 and this is recognised by Cohen (2015) possibly for the best one so far.

The literature indicates that the residents' voices are counting in cities which reached the 3.0 phase. In practice, this does not seem to be fully reflected due to the introduced participatory budgets in multiple cities that have not really reached any of smart city phases. What seems to be relevant at phase 3.0, that residents propose the solutions for the city because only then will they create the community which through its creativity impacts on an increasingly better quality of life in the urban space. Submitted tasks should be examined through such tools of social participation. It would give the answer to the concern if the society of a particular city is an initiator of solutions for the city and especially whether innovative projects appear.

For the analysis of ongoing projects under civic budgets in this publication smart city 0.0 phase has been adopted. The phase includes actions such as supplying of the equipment or conducting ICT training but with no element of data management which can build a system. 


\section{Methodology and results of civic budgets analysis in cities of Wielkopolska voivodeship in 2018}

Presented research results dedicated to civic budget implementation in cities of Wielkopolska voivodeship for 2018 are based on data included in reports about a municipality condition or websites dedicated to civic budgets of particular cities with a special focus on public information bulletin sites. All 113 cities in the voivodeship were covered by the study. The collected data was analyzed both quantitatively and qualitatively.

Although Poznan stood out from other units, it was decided not to reject it from the study, because the authors wanted a synthetic approach to the studied issues.

The study was carried out in three stages. At the first stage, the websites, mainly public information bulletin, of all 113 cities in Wielkopolska were reviewed (full study in FebruaryApril 2020), which allowed to diagnose the level of implementation of civic budgets in the surveyed population in 2018. At the second stage, information on all correctly submitted project applications (915) and the number of finally selected projects for implementation (279) were collected. In the third stage, ten winning projects were selected, based on using the information and communication technologies (ICT). Due to the difficulty of verifying activities in terms of being smart, a fairly simplified technological criterion was adopted, assuming that in order to achieve the smart city 2.0 phase a systemic approach based on the rapid flow of information between different devices is required. Additionally, as mentioned, the smart city 0.0 phase was added to indicate activities based on technology but without data management.

The review of reports revealed that out of 113 cities in the Wielkopolska Voivodeship, 34 cities in 2017 identified a pool of money in the city budget and allocated it to the implementation of the 2018 civic budget. This meant that civic budgeting covered an area inhabited by over 1,573 thousand people with a total area of $4198.8 \mathrm{~km}^{2}$. Although the average population density of the surveyed local government units equaled 654.95 people $/ \mathrm{km}^{2}$, as many as half of them were characterized by a density equal to or lower than 192.86 people $/ \mathrm{km}^{2}$.

The 2018 civic budget was owned by $31.1 \%$ of the cities in Wielkopolska. Three cities decided to additionally implement the village administrator's fund and $7.1 \%$ of the cities had only the village administrator's fund. Moreover, Września and Gostyń did not have their own civic budget for county civic budgets. Less than $60 \%$ of the cities covered by the study did not use any of these forms of social participation (Figure 1). 


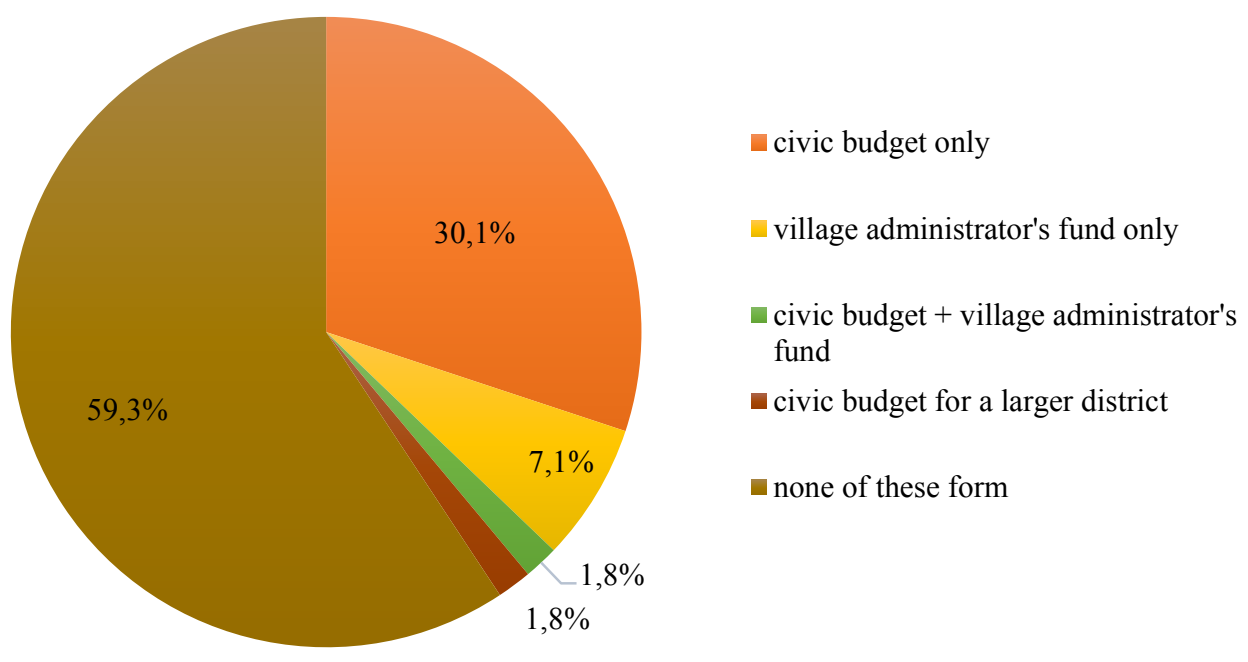

Figure 1. The percentage of Wielkopolska cities with a civic budget and a village council fund for 2018 . Source: own elaboration.

The process of preparing the civic budget was very different for each of the analyzed units. Therefore, it is difficult to talk about a single model of participatory budgeting as each city adopted its own regulations for conducting a civic budget by way of a resolution or ordinance of the executive body. However, it can certainly be said that the solutions concerning the civic budget procedure had common features and perhaps some of the solutions were copied from other units. The main differences referred to the time of submitting tasks and voting, the amount allocated to the civic budget and the formal conditions that the submitted project had to meet.

Promotion of the civic budgets of Wielkopolska cities took various forms. Information about them was most often found on the official websites of the cities and sometimes on the dedicated, official website of the civic budget for the city. For example, such internet platforms devoted only to the civic budget are available in Poznań (budzet.um.poznan.pl), Konin (www.kbo.konin.pl), and Szamotuły (szamotuly.budzet-obywatelski.org).

The analyzed units were both urban and urban-rural communes. Thus, some budgets included tasks strictly related to urban public space as well as tasks related to other places located in a given commune (Table 1). 
Table 1.

The cities of Wielkopolska voivodship implementing civil budgets in 2018

\begin{tabular}{|c|c|c|c|}
\hline \multicolumn{4}{|c|}{ Small cities (till 20000 inhabitatns) } \\
\hline $\begin{array}{l}\text { Cities } \\
\text { (till } 10000 \text { innabitants) }\end{array}$ & $\begin{array}{l}\text { Value of civic budget } \\
\text { (PLN) }\end{array}$ & $\begin{array}{l}\text { Cities } \\
(10000-20000 \\
\text { inhabitants })\end{array}$ & $\begin{array}{l}\text { Value of civic budget } \\
\text { (PLN) }\end{array}$ \\
\hline Bojanowo & 75000 & Czempiń & 50000 \\
\hline Książ Wielkopolski & 100000 & Kłodawa & 400000 \\
\hline Puszczykowo & 100000 & Kostrzyn & 250000 \\
\hline Szamocin & 200000 & Międzychód & 365633,8 \\
\hline \multirow[t]{4}{*}{ Ujście } & 140000 & Stupca & 120000 \\
\hline & & Śmigiel & 160000 \\
\hline & & Witkowo & 100000 \\
\hline & & Złotów & 500000 \\
\hline \multicolumn{4}{|c|}{ Medium cities (20000. -100000 inhabitants) } \\
\hline $\begin{array}{l}\text { City } \\
(20000-40000 \\
\text { inhabitants) }\end{array}$ & $\begin{array}{l}\text { Value of civic budget } \\
\text { (PLN) }\end{array}$ & $\begin{array}{l}\text { City } \\
(40000-100000 \\
\text { inhabitants }\end{array}$ & $\begin{array}{l}\text { Value of civic budget } \\
\text { (PLN) }\end{array}$ \\
\hline Grodzisk Wielkopolski & 200000 & Gniezno & 500000 \\
\hline Kępno & 300000 & Kalisz & 5000000 \\
\hline Kórnik & 700000 & Konin & 2000000 \\
\hline Luboń & 250000 & Leszno & 1000000 \\
\hline Mosina & 947923 & Ostrów Wielkopolski & 1000000 \\
\hline Nowy Tomyśl & 250000 & Piła & 3000000 \\
\hline Pleszew & 500000 & Śrem & 700000 \\
\hline Rawicz & 650000 & Swarzędz & 1500000 \\
\hline Szamotuły & 500000 & & \\
\hline Turek & 500000 & & \\
\hline Wagrowiec & 250000 & & \\
\hline Wolsztyn & 300000 & & \\
\hline \multicolumn{4}{|c|}{ Big cities (over 100000 inhabitants) } \\
\hline \multicolumn{2}{|c|}{ City } & \multicolumn{2}{|c|}{ Value of civic budget (PLN) } \\
\hline \multicolumn{2}{|l|}{ Poznań } & \multicolumn{2}{|l|}{18000000} \\
\hline
\end{tabular}

Source: own elaboration using scale proposed in GUS (2018).

Medium-sized cities were the largest group among all 34 cities in which the 2018 civic budget was created and in their case $66.7 \%$ of all medium-sized cities in the Wielkopolska voivodeship implemented the civic budget. In small towns, the civic budget was considered in $15.9 \%$ of cases. The smallest city in terms of the number of inhabitants in which the civic budget was implemented was Szamocin, the largest was Poznań.

The process of collecting ideas for voting also depended on the local government, which could impose restrictions. One of the most important was the amount of the city budget allocated to the implementation of the civic budget. It usually ranged from $0.5 \%$ to $1 \%$ of the city budget. Another limitation, which occurred especially in larger cities was the imposition of a task category.

Ideas were divided into the following categories: investment and non-investment, large and small, hard and soft and general city and neighborhood (district).

Notifications of activities could usually be submitted by residents, non-governmental organizations, organizations of auxiliary units of local government or organizational units of 
the commune. In the case of cities of Wielkopolska, almost all ideas were submitted by the inhabitants.

The verification of submitted ideas consists of meeting the formal and substantive requirements. Formal requirements usually consisted of completing mandatory fields in the form and submitting the document on time. Then, it was checked whether the task was feasible, e.g. in terms of costs, compliance with the development strategy of the individual, or the place of implementation in the urban space. For instance, 165 applications were rejected in Poznań's civic budget for 2018 and 38 in Kalisz.

In 2018, 915 applications were correctly submitted to the civic budgets, while Poznan itself had 160 tasks qualified for voting (17.5\% of all applications). On average, there were 26.91 such applications per city (Table 2).

Table 2.

Selected information on cities of Wielkopolska implementing civic budgets in 2018

\begin{tabular}{|c|c|c|c|c|c|c|}
\hline Statistical measurement & Average & Median & $\begin{array}{l}\text { Stadndard } \\
\text { deviation }\end{array}$ & Minimum & Maximum & Total \\
\hline Numer of inhabitatnts & 46275,00 & 26870,50 & 89527,42 & 7508,00 & 536438,00 & 1573350 \\
\hline $\begin{array}{l}\text { Area of the municupality } \\
\left(\mathrm{km}^{2}\right)\end{array}$ & 123,49 & 128,50 & 78,06 & 10,00 & 307,20 & 4198,8 \\
\hline \begin{tabular}{|l|}
$\begin{array}{l}\text { Density of population } \\
\left(\text { person } / \mathrm{km}^{2}\right)\end{array}$ \\
\end{tabular} & 654,95 & 192,86 & 735,64 & 57,08 & 2352,55 & \\
\hline \begin{tabular}{|l|} 
Ratio of voters to the \\
number of inhabitants * the \\
indicator does not include \\
data for two cities for \\
which information has not \\
been disclosed \\
\end{tabular} & $16 \%$ & $15 \%$ & $9 \%$ & $0 \%$ & $34 \%$ & \\
\hline $\begin{array}{l}\text { Vakue of civic budgets } \\
\text { (in thousand PLN) }\end{array}$ & 1194,36 & 382,82 & 3124,69 & 50,00 & 18000,00 & 40608,56 \\
\hline $\begin{array}{l}\text { The amount of the civic } \\
\text { budget per capita } \\
\text { (PLN/person) }\end{array}$ & 18,29 & 16,34 & 10,82 & 4,36 & 51,20 & \\
\hline $\begin{array}{l}\text { Number of Projects } \\
\text { qualified for voting }\end{array}$ & 26,91 & 12,5 & 37,40 & 2 & 160 & 915 \\
\hline $\begin{array}{l}\text { Number of Winning } \\
\text { projects selected for } \\
\text { implementation }\end{array}$ & 8,21 & 4,5 & 11,53 & 1 & 56 & 279 \\
\hline
\end{tabular}

Źródło: opracowanie własne.

The projects proposed in them most often concerned the construction or renovation of roads, sidewalks, bicycle paths or parking lots, renovation of schools, construction of a playground, playgrounds, outdoor gyms, monitoring installations, providing lighting, revitalizing green spaces or meeting places, or organizing events for the local community. Less frequently, the applications referred to the support for the elderly, the disabled, the protection of cultural goods or the care of stray dogs and cats (Fig. 2). 


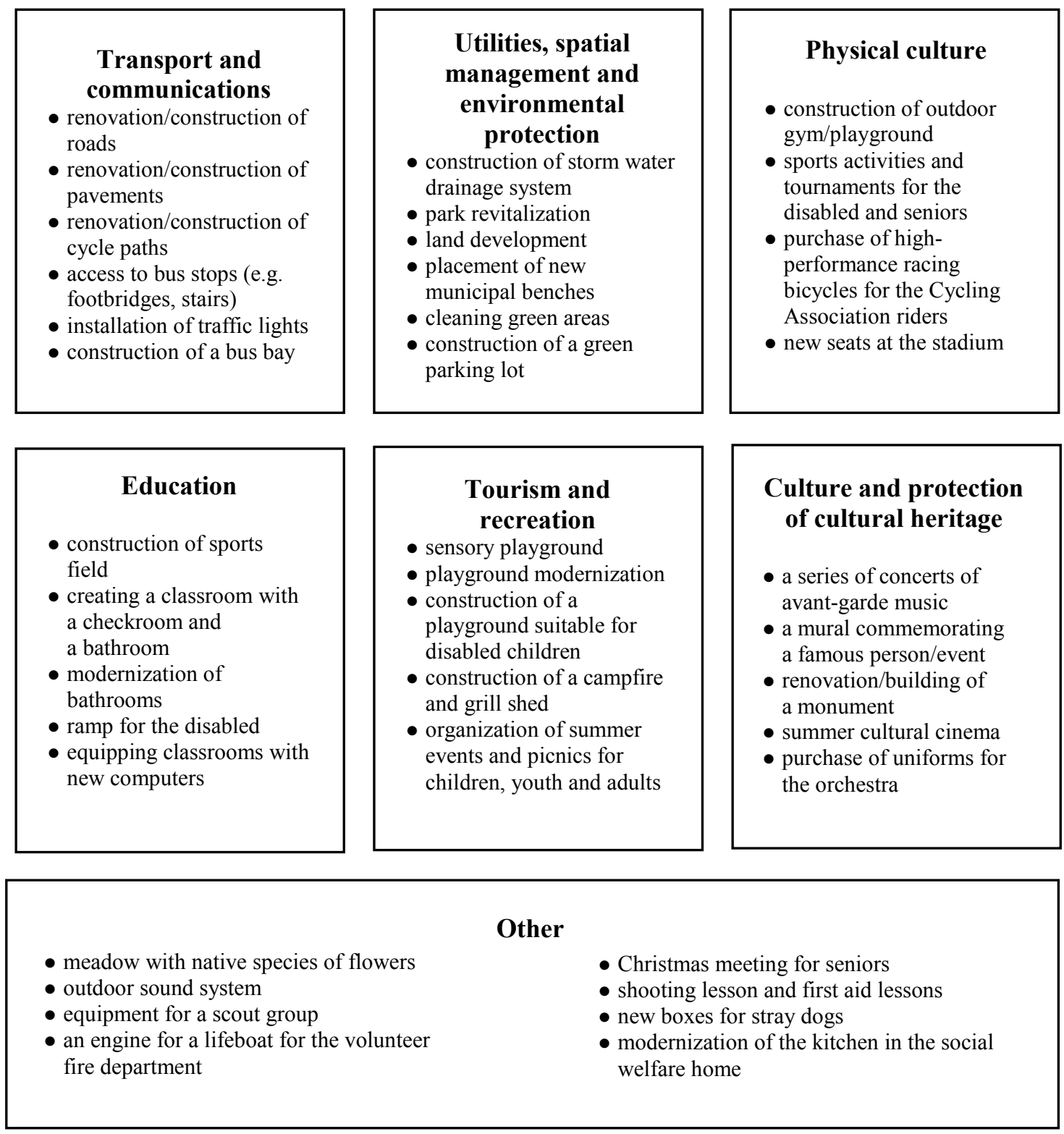

Figure 2. Examples of tasks submitted to civic budgets for 2018. Source: own elaboration.

Voting was common, it was possible to vote both online and in a traditional way and it was possible to vote for several days or more. The voting results depended on civic involvement, both at the stage of submitting tasks and voting itself.

The ratio of the number of voters to the number of inhabitants was comparable for many surveyed entities, on average it amounted to $16 \%$ (Table 2). The highest value of the index was achieved by Czempiń - 34\%. The lowest value was $0 \%$, as no voting took place in Grodzisk Wielkopolski. Four tasks were submitted there, the total costs of which were in the amount of the civic budget, hence, submitted projects automatically became successful.

Wielkopolska cities allocated a total of 40,608.56 thousand PLN in civic budgets in 2018. The average value of the civic budget for the city was 1,194.36 thousand PLN, but for as many as half of this value did not exceed 382.82 thousand PLN. Poznań allocated the most for this purpose $-18,000$ thousand PLN, the least Czempin - 50 thousand PLN. The amount of the 
civic budget per capita ranged between PLN 4.36 and PLN 51.20, but the maximum value differed significantly from the average of PLN 18.29.

The winning projects, 279 in total, accounted for $30.5 \%$ of the projects qualified for voting. As a result of voting, on average 8.21 projects were selected for implementation but half of the cities had exactly or less than 4.5 winning projects. In the tested group, the number of winning tasks deviated from the arithmetic average for about $+/-11.53$ tasks, which proves the high variability of the number of winning projects for individual cities. Despite this variation, the number of voted projects was strongly correlated with the number of projects qualified for voting (Pearson's index: 0.864). In one of the analyzed cities only one task was selected for implementation, the leader in this category had 56 winning projects (Table 2).

Less than 1/3 of Wielkopolska cities, i.e. 34 out of 113 had a civic budget for 2018 , although various forms of residents co-decision in communes were carried out in $40 \%$ of cities in Wielkopolska. Some urban-rural communes did not use this tool for the village funds. Interest in the civic budget varied, both at the stage of submitting projects and voting. Almost $1 / 3$ of all tasks qualified for voting were outvoted and entered into the budgets of municipalities for 2018 .

In 2018, civic budgets fulfilled their role, it can be admitted that most of their implementation was successful. It is difficult to assess whether local authorities with a very small number of projects or with a very low turnout achieved the expected results. Perhaps participatory budgeting is not the expected form of social participation there, or the entire procedure is too complicated. The number of civic budgets in 2018 in the Greater Poland Voivodeship does not prove the universal use of this tool, but it is certainly a signal that local authorities want to give votes to their residents. Still, to a large extent, projects submitted to the budget are investment tasks consisting of renovation or construction of municipal infrastructure. However, the reported number of tasks related to sport, culture or tourism proves that the inhabitants expect from the city not only infrastructural investments, but also activities for the development of the individual and spending time in the city's public space.

The multiplicity and type of tasks hidden under the category of "other" proves that the inhabitants of the Wielkopolska voivodeship are active observers of life in the city and can be creators of projects, also unconventional, which will improve the quality in their life, directly tailored to the needs of a given community. This gives grounds for the conclusion that when the basic needs of the inhabitants are satisfied, they will start reporting innovative tasks in the process of civic budgeting. 


\section{Evaluation of smart city projects implemented as part of civic budgets in cities of Wielkopolska in 2018}

Secondary analysis of civic budgets is the next step of the research procedure and allows to recognize what types of needs are reported by the city's stakeholders and whether there are tasks for smart city concept among them.

Examples and considerations in the literature (introduction) allow us to state a shift of emphasis in civic budgets from investment tasks related to basic urban infrastructure, to tasks related to education, culture, tourism, health and nature protection and other tasks improving the quality of living in urban space. This direction of changes is the theoretical confirmation that cities are developing and that their inhabitants will start proposing innovative activities.

The continuation of considerations on the projects of civic budgets was aimed at assessing these tasks in terms of fitting them into the smart city concept. Due to the difficulty of verifying activities in terms of being smart, the results were based on a list of tasks that clearly fit into the idea of the smart city project. The use of technology in the project served as a distinguishing criterion.

In 2018, 34 smart city projects were included in the proposed tasks for the civic budgets of cities of Wielkopolska. They accounted for $3.7 \%$ of all qualified tasks. The proposed tasks (Fig. 3) were of both investment and non-investment nature. Half of the projects concerned increasing security, which, in the opinion of the applicants, could improve thanks to the monitoring of urban spaces, easily accessible AED defibrillators, intelligent pedestrian crossings and air monitoring using an anti-smog drone. The potential of introducing smart solutions has been noticed in senior citizens and children.

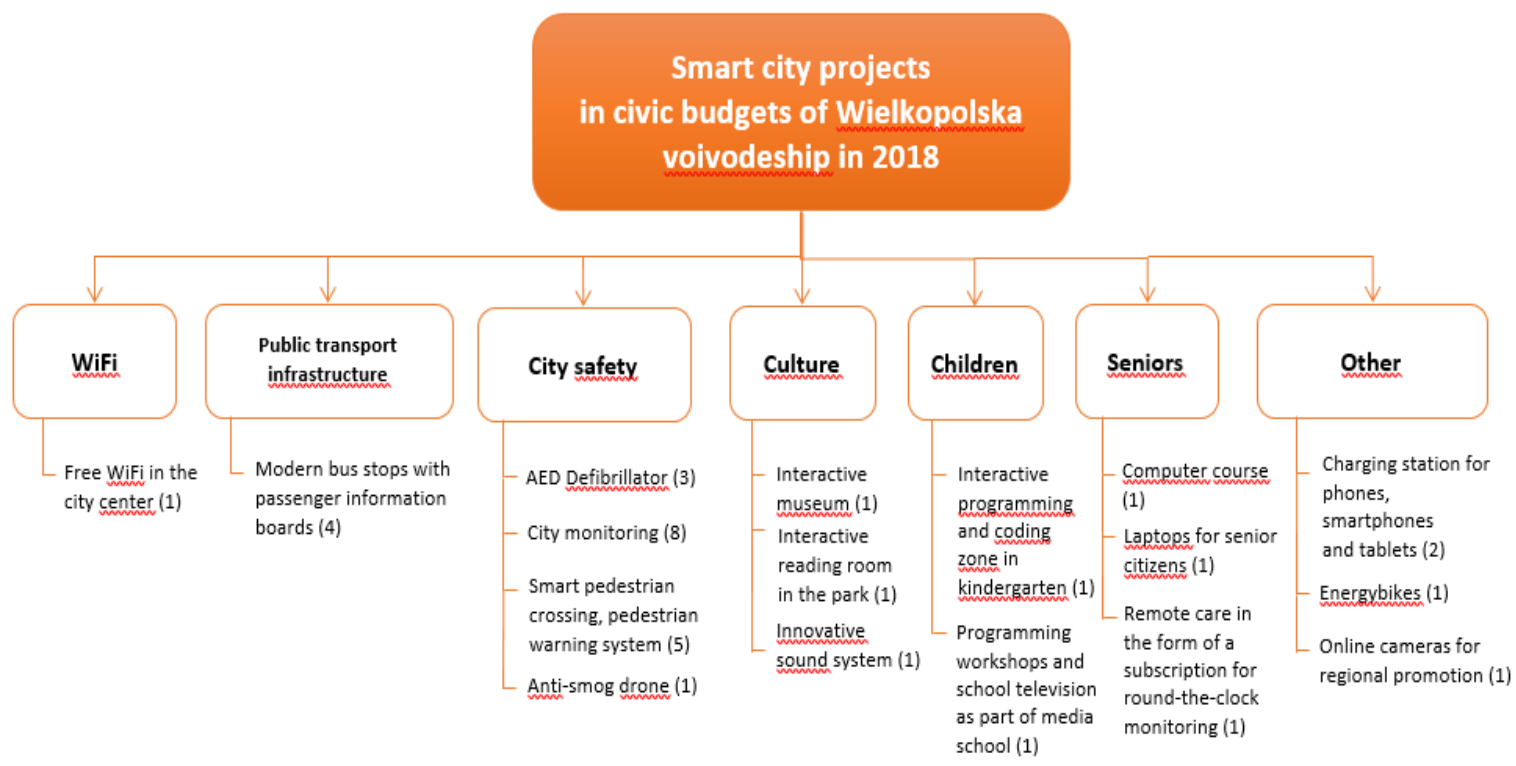

Figure 3. Smart city projects qualified for voting in Wielkopolska civic budgets for 2018 (the number in brackets indicates the number of projects submitted). Source: own elaboration. 
In the first group, applications were made for extending IT knowledge and remote care based on monitoring, and the second group was proposed to create a media school with programming courses, or to initiate an interactive zone with programming and coding for kindergarten children. Other tasks, among others, were focused on the sphere of culture, public transport, access to an Internet by free $\mathrm{Wi}-\mathrm{Fi}$, or the creation of a small urban infrastructure that will allow to charge a phone or a tablet.

Among the tasks chosen to voting, 10 projects were selected for implementation (Table 3). Their review is important because only the winning projects testify to the needs of local communities.

Three projects were selected from Kalisz, two from Piła and one each from Poznań, Ostrów Wielkopolski, Kórnik, Mosina and Książ Wielkopolski, which means that $80 \%$ of the tasks were outvoted in medium-sized cities (from 20,000 to 100,000 inhabitants), $10 \%$ in a small city (up to 20,000 inhabitants) and $10 \%$ in a large city (over 100,000 inhabitants). However, this is not a sufficient attempt to draw conclusions about where smart city initiatives are most often created.

\section{Table 3.}

Overview of smart city projects implemented as part of civic budgets (CB) in Wielkopolska in 2018

\begin{tabular}{|c|c|c|c|c|c|}
\hline $\begin{array}{l}\text { SMART } \\
\text { CITY } \\
\text { AREA }\end{array}$ & TASK & CITY & BUDGET & $\begin{array}{l}\text { STAKE- } \\
\text { HOLDERS }\end{array}$ & $\begin{array}{l}\text { TECHNOLOGY USED/ } \\
\text { SMART CITY PHASE }\end{array}$ \\
\hline 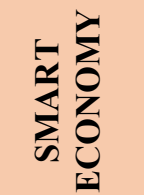 & No data & No data & No data & No data & No data \\
\hline \multirow{3}{*}{ 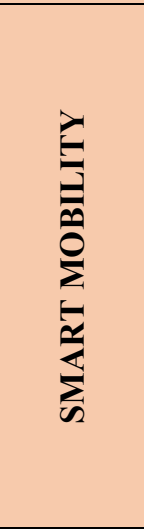 } & $\begin{array}{l}\text { Smart } \\
\text { pedestrian } \\
\text { crossing }\end{array}$ & Piła & No data & $\begin{array}{l}\text { Inhabitants, } \\
\text { touristst }\end{array}$ & $\begin{array}{l}\text { Service improvement action, data- } \\
\text { driven technology, investment for } \\
\text { specific application. Smart City } 1.0 \text {. } \\
\text { phase }\end{array}$ \\
\hline & $\begin{array}{l}\text { Smart } \\
\text { pedestrian } \\
\text { crossing }\end{array}$ & Piła & No data & $\begin{array}{l}\text { Inhabitants, } \\
\text { touristst }\end{array}$ & $\begin{array}{l}\text { Service improvement action, data- } \\
\text { driven technology, investment for } \\
\text { specific application. Smart City } 1.0 \text {. } \\
\text { phase }\end{array}$ \\
\hline & $\begin{array}{l}\text { A modern bus } \\
\text { stop with a } \\
\text { passenger } \\
\text { information } \\
\text { system board }\end{array}$ & Poznań & $\begin{array}{l}500000 \\
\text { PLN } \\
(2,7 \% \mathrm{CB} \\
\text { of the city) }\end{array}$ & Passengers & $\begin{array}{l}\text { Action based on the need to exchange } \\
\text { data, there is cooperation between } \\
\text { systems. Smart City 2.0. phase }\end{array}$ \\
\hline 空 & No data & No data & No data & No data & No data \\
\hline
\end{tabular}


Cont. table 3.

\begin{tabular}{|c|c|c|c|c|c|}
\hline \multirow{3}{*}{ 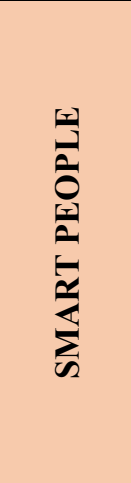 } & $\begin{array}{l}\text { Computer } \\
\text { course for } \\
\text { seniors }\end{array}$ & Kórnik & $\begin{array}{l}8500 \text { PLN } \\
(1,2 \% \text { CB } \\
\text { of the city) }\end{array}$ & Seniors & $\begin{array}{l}\text { Action aimed at improving the } \\
\text { quality of life. An investment for } \\
\text { a specific application. } \\
\text { Smart City } 0.0 . / 1.0 \text {. phase }\end{array}$ \\
\hline & $\begin{array}{l}\text { Small Media } \\
\text { School }\end{array}$ & $\begin{array}{l}\text { Ostrów } \\
\text { Wielko- } \\
\text { polski }\end{array}$ & $\begin{array}{l}24840 \text { PLN } \\
(2,5 \% \mathrm{CB} \\
\text { of the city) }\end{array}$ & Children & $\begin{array}{l}\text { Action aimed at improving the } \\
\text { quality of life. An investment for } \\
\text { a specific application. } \\
\text { Smart City } 0.0 . / 1.0 \text {. phase }\end{array}$ \\
\hline & $\begin{array}{l}\text { Interactive } \\
\text { zone for } \\
\text { programming } \\
\text { and coding }\end{array}$ & Kalisz & $\begin{array}{l}57035 \text { PLN } \\
(1,1 \% \mathrm{CB} \\
\text { of the city) }\end{array}$ & Children & $\begin{array}{l}\text { Action aimed at improving the } \\
\text { quality of life. An investment for } \\
\text { a specific application. } \\
\text { Smart City } 0.0 . / 1.0 \text {. phase }\end{array}$ \\
\hline \multirow{4}{*}{ 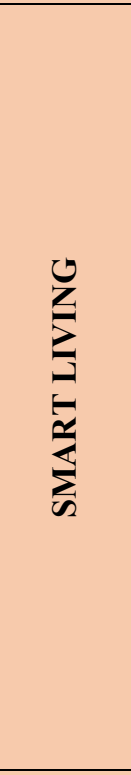 } & $\begin{array}{l}\text { AED } \\
\text { defibrillator in } \\
\text { public } \\
\text { institutions }\end{array}$ & Kalisz & $\begin{array}{l}60000 \text { PLN } \\
(1,2 \% \mathrm{CB} \\
\text { of the city) }\end{array}$ & $\begin{array}{l}\text { Inhabitants, } \\
\text { touristst }\end{array}$ & $\begin{array}{l}\text { Action aimed at improving the } \\
\text { quality of life. } \\
\text { Smart City } 0.0 . / 1.0 \text {. phase (applies } \\
\text { to the installation of devices itself). }\end{array}$ \\
\hline & Free WiFi & Konin & $\begin{array}{l}58056 \text { PLN } \\
(2,9 \% \mathrm{CB} \\
\text { of the city) }\end{array}$ & $\begin{array}{l}\text { Inhabitants, } \\
\text { touristst }\end{array}$ & $\begin{array}{l}\text { Action aimed at improving the } \\
\text { quality of life. An investment for } \\
\text { a specific application. } \\
\text { Smart City } 0.0 . / 1.0 \text {. phase }\end{array}$ \\
\hline & $\begin{array}{l}\text { AED } \\
\text { defibrillator } \\
\text { for volunteer } \\
\text { Fire } \\
\text { Department }\end{array}$ & $\begin{array}{l}\text { Książ } \\
\text { Wielko- } \\
\text { polski }\end{array}$ & $\begin{array}{l}7200 \text { PLN } \\
(7,2 \% \text { CB } \\
\text { of the city) }\end{array}$ & $\begin{array}{l}\text { Inhabitants, } \\
\text { touristst }\end{array}$ & $\begin{array}{l}\text { Action aimed at improving the } \\
\text { quality of life. An investment for } \\
\text { a specific application. } \\
\text { Smart City } 0.0 . / 1.0 \text {. phase (applies to } \\
\text { the installation of devices itself). }\end{array}$ \\
\hline & $\begin{array}{l}\text { Village } \\
\text { Monitoring }\end{array}$ & Mosina & $\begin{array}{l}77066 \text { PLN } \\
(8,1 \% \mathrm{CB} \\
\text { of the city) }\end{array}$ & $\begin{array}{l}\text { Inhabitants } \\
\text { of the village }\end{array}$ & $\begin{array}{l}\text { Reaction After starting real-time } \\
\text { signal transmission to the } \\
\text { headquarters of the municipal police } \\
\text { - a holistic way of thinking and } \\
\text { cooperation of systems Smart City } \\
\text { 2.0. phase }\end{array}$ \\
\hline 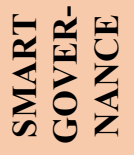 & No data & No data & No data & No data & No data \\
\hline
\end{tabular}

Source: own elaboration.

The verification of projects in terms of their advancement in the smart city concept, included in Table 3, allows the following conclusions to be drawn:

1) None of the won tasks covered any areas of smart economy, smart environment and smart governance. It can be assumed that smart economy and smart governance are not the domain of residents, so they do not submit tasks related to these areas of smart city. The lack of projects in the area of smart environment may mean that such tasks were not submitted or even when submitted, their nature did not include the use of technology, therefore they were not included in the study.

2) Some of the tasks were selective and marginal. The task outvoted in Poznan was a continuation of the development of the ITS Poznan System.

3) The winning projects came from every type of city, which shows that smart city projects are not only the preferences of large metropolises residents.

4) About $90 \%$ of won tasks came from medium and large cities. However, the sample is too small (10 projects) to be able to draw conclusions about the needs of smart city 
communities in these cities, even though it represents a full population of smart city projects in the region according to the adopted criteria.

5) The won tasks were a response to the needs related to safety, health protection, education, counteracting digital exclusion, revitalization of public space, access to information and Internet access.

6) Assuming that the residents treated smart city projects as needs of a higher order, the small number of won smart city tasks in relation to other tasks allows us to assume that there were still many lower-order needs (e.g. repair of the road surface) that require implementation.

7) The number of submitted and won smart city projects indicates that voters in civic budgets did not treat smart city activities in the city as a priority (less than $30 \%$ of projects were selected for implementation).

8) The implementation of one smart city project consumed on average $3.36 \%$ of the city's civic budget, no city allocated more than $8.1 \%$ of the civic budget to the implementation of the smart city project (no data for Piła did not allow to include the city in this statistics).

9) Stakeholders of the winning projects were both all city residents and specific groups of recipients: in the case of civic budgets for 2018, they were senior citizens, children, only residents of a given place, tourists or only public transport passengers. There were no specific professional group or environmental tasks.

10) The degree of technology involvement in the won tasks varied. Some projects (e.g. WiFi access, defibrillator installation) were aimed at improving the service, without having the technology to be specially adapted to the task. Other projects, e.g. monitoring with real-time transmission of information to the municipal police or the ITS system in Poznań, already prove the need to collect and update data, and thus to create the architecture of ICT systems or sensor networks.

11) The analysis of the projects did not allow to answer the question of whether the community is able or willing to initiate tasks with a high degree of integration and technology advancement. Undoubtedly, the amount of civic budgets to a large extent limits the possibility of creating ideas of such a format. A sufficiently high budget could result in the emergence of more technologically advanced solutions for cities.

12) The won tasks were characteristic for the smart city phases of $0.0,1.0$ and 2.0. This shows that the inhabitants were mainly task-oriented, focused on satisfying a given need in a short run, and rarely treated the problem holistically and systematically. 


\section{Conclusions and limitations of the study}

The results obtained through the 2018 review of civic budgets of cities in Wielkopolska Voivodeship are of a diagnostic and research nature. The conclusions apply to all cities of Wielkopolska, so generalizations can only be done to this region at a strictly defined time, therefore they should not be applied to other places or generalized. Only $40 \%$ of cities in Greater Poland region created civic budgets which leaves a lot of space for improving the inclusion of inhabitants in the co-management of the municipality. Projects selected for implementation under civic budgets are still largely of investment nature, consisting of renovation or construction of municipal infrastructure. Importantly, a considerable number of tasks related to sport, culture and tourism were reported, which proves that the inhabitants expect the city not only for infrastructure investments, but also for activities helping to spend time in the city's public space and developing of individual's life quality.

At the first stage, smart city projects focus on simple activities improving life, especially in the area of smart living, while attempts to implement system solutions withing smart city $2.0+$ phases are carried out at this stage only in the Poznań agglomeration.

As for the limitations of the study, it is worth repeating the research on the quality of projects approved for implementation under civic budgets both in Wielkopolska and in other regions of Poland. In the future research, it is worth extending the understanding of smart city projects beyond the use of information and communication technologies. Such a comprehensive list could be helpful for the formulation of urban policy assumptions, which is required at the smart city 2.0 and 3.0 phases.

Undoubtedly, the described issue requires further research, therefore the presented considerations may, above all, serve as an inspiration to continue research on the importance of the smart city concept in civic budgets.

\section{References}

1) Burchard-Dziubińska, M. (2016). Budżet obywatelski jako narzędzie realizacji rozwoju zrównoważonego na poziomie lokalnym - przykład Łodzi. Studia i Prace WNEIZ US 4691, pp. 235-246.

2) Cohen, B. (2015). Retrieved from The 3 Generations of Smart Cities. Inside the development of the technology driven city, https://www.fastcompany.com/3047795/the-3generations-of-smart-cities.

3) Daniel, K. (2019). Budżet obywatelski - analiza porównawcza Gorzowa Wielkopolskiego i Opola. Kwartalnik Prawo-Społeczeństwo-Ekonomia, 4, pp. 5-22. 
4) Gałecki, A. (2013). Budżet obywatelski w mieście Łodzi. In: M. Ćwilkicki, M. Frączek, Partycypacja społeczna w Polsce. Atlas dobrych praktyk. Kraków: Fundacja Gospodarki i Administracji Publicznej.

5) GUS (2018). Miasta w liczbach. Poznań: Główny Urząd Statystyczny.

6) Jeran, A., Mączka, K., Matczak, P., \& Milewicz, M. (2017). Charakterystyka procedur budżetów obywatelskich w Wielkopolsce. Studia Humanistyczne AGH, 16(3), pp. 43-57.

7) Kołodziej-Hajdo, M. (2017). Budżet partycypacyjny jako instrument zarządzania publicznego w koncepcji Public Governance na przykładzie miasta Krakowa. Zeszyty Naukowe Uniwersytetu Ekonomicznego w Katowicach, 341, pp. 159-170.

8) Komninos, N. (2008). Retrieved from Intelligent Cities and Globalisation of Innovation Networks, http://www.stellenboschheritage.co.za/wp-content/uploads/Intelligent-Citiesand-Globalisation-of-Innovation-Networks.pdf.

9) Krawczyk, A. (2016). Doskonalenie modelu budżetu obywatelskiego na przykładzie miasta Częstochowy. Zeszyty Naukowe Politechniki Częstochowskiej. Zarządzanie, $n r$ 22, pp. 242-256.

10) Laurisz, N. (2013). Wprowadzenie do partycypacji społecznej w Polsce. In: M. Ćwilkicki, \& M. Frączek, Partycypacja społeczna w Polsce. Atlas dobrych praktyk. Kraków: Fundacja Gospodarki i Administracji Publicznej.

11) Lewicki, M., \& Romanowski, R. (2017). Znaczenie koncepcji smart city w marketingu terytorialnym. Roczniki Kolegium Analiz Ekonomicznych, nr 45, pp. 117-129.

12) Lombardi, P., Giordano, S., Farouh, H., \& Yousef, W. (2012). Modelling the smart city performance innovation. Innovation: The European Journal of Social Science Research, 25(2), DOI: 10.1080/13511610.2012.660325, pp. 137-149.

13) Łukomska-Szarek, J. (2014). Budżetowanie partycypacyjne jako instrument współzarządzania sferą publiczną. Nierówności Społeczne a Wzrost Gospodarczy, 4, pp. 137-144.

14) Masik, G., \& Studzińska, D. (2018). Evolution of the Smart City concept and of research into it. Przeglad Geograficzny, 90(4), pp. 557-571.

15) Obrębalski, M. (2016). Specjalizacja i inteligencja miasta - identyfikacja, pomiar i ocena. Studia Komitetu Przestrzennego Zagospodarowania Kraju PAN, 170, pp. 112-124.

16) Paliński, M. (2019). Retrieved from Inteligentne miasto: filozofia łączy się z informatyką, https://regiony.rp.pl/trendy/smart-city/18507-inteligentne-miasto-filozofia-laczy-sie-zinformatyka.

17) Rudewicz, J. (2019). Przemysł i technologie wobec wdrożenia wizji miasta inteligentnego (smart city). Prace Komisji Geografii Przemystu Polskiego Towarzystwa Geograficznego, 33(4), pp. 194-212.

18) Sobol, A. (2017). Budżet obywatelski jako narzędzie rozwoju lokalnego. Studia Ekonomiczne, 316, pp. 172-182. 
19) Studencka, K. (2017). Budżet obywatelski w Katowicach i jego konsekwencje w przestrzennym zagospodarowaniu miasta. Budownictwo i Architektura, 16(2), pp. 81-88.

20) Tatarowska, E., \& Furmankiewicz,, M. (2018). "Wrocławski budżet obywatelski 2014" jako przestrzenna forma identyfikacji potrzeb inwestycyjnych w mieście. Prace Naukowe Uniwersytetu Ekonomicznego we Wroctawiu. Gospodarka przestrzenna - stan obecny i wyzwania przyszłości, 504, pp. 120-133.

21) Ustawa o zmianie niektórych ustaw w celu zwiększenia udziału obywateli w procesie wybierania, funkcjonowania i kontrolowania niektórych organów publicznych, Dz.U. z 2018 poz. 130 (01.11.2018).

22) Ustawa z dnia 8 marca 1990 r. o samorządzie gminnym, Dz. U. z 2020 r. poz. 713, art. 28aa (03.08.1990).

23) Wampler, B. (2007). A guide to participatory budgeting. In: A.S. (ed.), Participatory budgeting (pp. 21-54). Washington: The World Bank.

24) Wiśniewska, M. (2018). Budżet obywatelski w polskich miastach - doświadczenia w województwie łódzkim. Studia miejskie, 29, pp. 91-99.

25) Zawieska, J. (2016). Inteligentne miasta $w$ Polsce a cele polityki transportowej Unii Europejskiej (Praca doktorska). Warszawa: Szkoła Główna Handlowa. 